ADALAH : Buletin Hukum \&

Keadilan

Buletin Hukum \& Keadilan

@adalahuinjkt

\title{
Deparpolisasi Partai Sebagai Motif Timbulnya Calon Perseorang
}

Nur Rohim Yunus*

Salah satu fungsi partai politik adalah menjadi sarana partisipasi politik warga negara Indonesia. Tetapi sayangnya, fungsi sentral tersebut mengalami degradasi. Sedikit demi sedikit, partai politik mengalami proses pelemahan yang sering disebut sebagai deparpolisasi.

Deparpolisasi terjadi sebagai akibat dari adanya perubahan peraturan perundang-undangan, putusan hakim, maupun persepsi publik, atau sikap amoral dari anggota partai politik. Adanya deparpolisasi ini mengakibatkan partai politik mengalami krisis kepercayaan yang berakibat pada timbulnya calon kepala daerah yang berasal dari perseorangan atau independen.

Secara yuridis, undangundang tentang pemerintahan daerah mengatur bahwa pasangan calon kepala daerah harus diajukan oleh partai politik atau gabungan partai politik, sehingga dominasi partai politik dalam hal ini sangat besar. Tetapi pasca putusan Mahkamah Konstitusi Nomor 5/ PUU-V/2007 calon kepala daerah perseorangan atau independen dapat menjadi peserta pilkada. Lan-

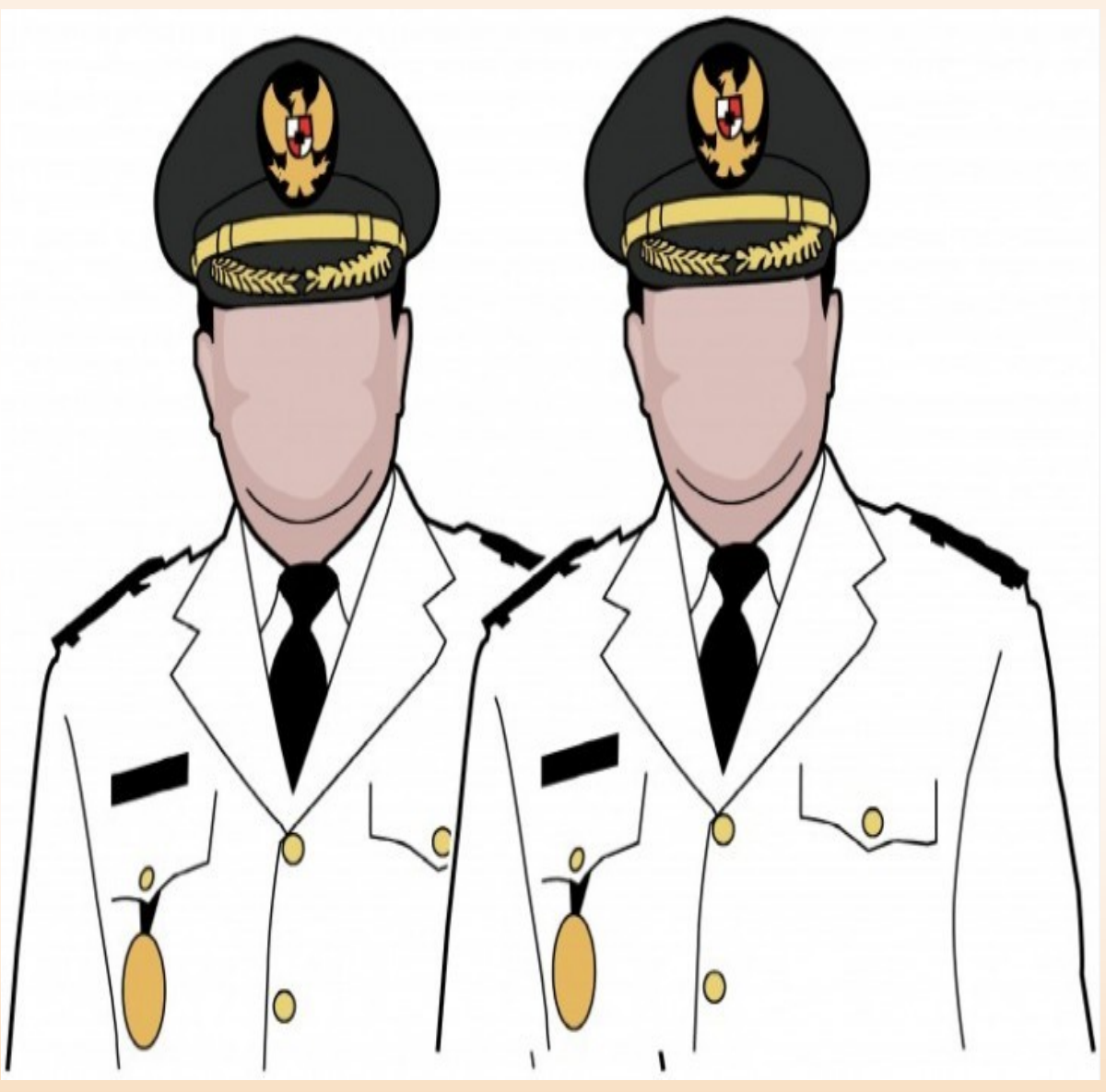

dasan berpikir dalam putusan MK

Dampak putusan MK terseini didasarkan penafsiran bahwa pemilihan kepala daerah yang demokratis dalam pasal 18 ayat (4) UUD 1945 memberikan peluang kepada calon perseorangan untuk mengajukan diri dalam pilkada, sehingga dalam pilkada calon kepala daerah perseorangan dapat bersaing dengan calon kepala daerah dari partai politik. but berakibat adanya pandangan bahwa partai bukanlah satu-satunya sarana politik bagi warga negara untuk berpartisipasi dalam pilkada. Lagi-lagi partai politik mengalami deparpolisasi dari sudut peran dan kedudukan sebagai kendaraan politik demokrasi.

Deparpolisasi sejak awal dianggap sebagai faktor utama tim- 
bulnya calon perseorangan. Artinya calon perseorangan lahir dari adanya kemerosotan kepercayaan publik terhadap partai politik.

Pada dasarnya, pemilihan kepala daerah harus didasarkan pada prinsip demokrasi, sehingga harus mampu memberi akses yang luas bagi segala kekuatan dalam masyarakat selaku pemegang kendali kedaulatan sebagaimana tercantum dalam pasal 1 ayat (2) UUD 195 yang berbunyi "Kedaulatan berada di tangan rakyat dan dilakukan menurut Undang-Undang Dasar."

Akan tetapi rakyat sebagai pemegang kendali kedaulatan sebagaimana prinsip demokrasi tidaklah seratus persen benar. Karena pada dasarnya kaum pemilik harta dan modal saja yang mengambil peran, termasuk dalam hal ini membentuk partai politik, maupun meniadakannya.

Hal ini sebagaimana pandangan Hanafi dalam jurnal cita hukum yang menyatakan (Hanafi, 2013:
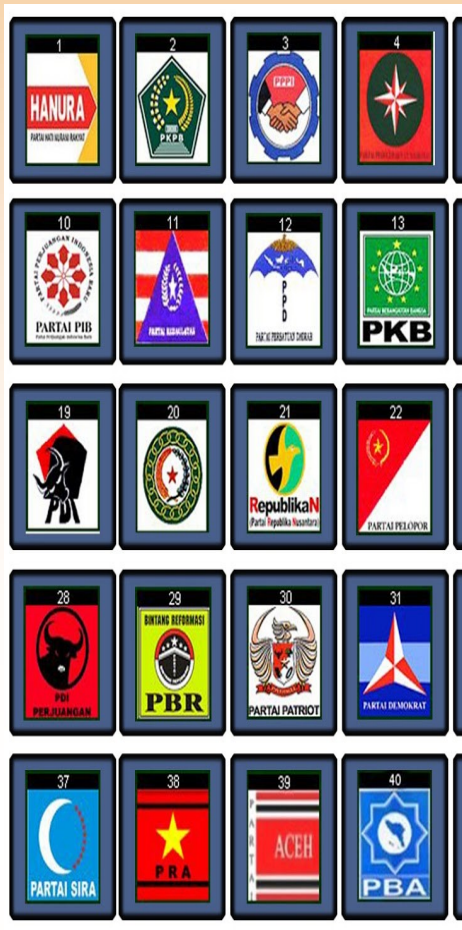
243):

“Memang rakyat dalam demokrasi sama sekali tidak punya hak dalam menentukan ini dan itu untuk kehidupannya, pemilik hak untuk menentukan calon pemimpin, calon wakil rakyat, penentu program apa yang harus dibangun dan dijalankan oleh pemenang pemilu di pemerintahan, bukan rakyat, akan tetapi mereka para hartawan, pengusaha, dan para investor bersama dengan para petinggi partai yang membiayai hidup matinya sebuah partai, guna kepentingan kekuasaan individu dan kelompoknya partai. Sekali lagi, rakyat hanya berpartisipasi untuk memilih mereka, inilah realitas demokrasi.

Walau pun demikian, di negara demokrasi, rakyat memiliki kedaulatan dimana hak-hak individu rakyat sangat dihargai dan dijamin kebebasannya, ter- masuk dalam hal menggunakan hak politik yang diatur dalam hukum. Rakyat memegang kendali dalam hal menentukan apakah suatu partai politik dapat dijadikan panutan atau malah ditinggalkan. Rakyat memiliki kebebasan dalam menentukan sikap terhadap partai yang ada.

Hal ini sebagaimana pendapat Khairul Fahmi bahwa suatu tatanan masyarakat, khususnya masyarakat demokratis memiliki kebebasan dan tanggung ja-

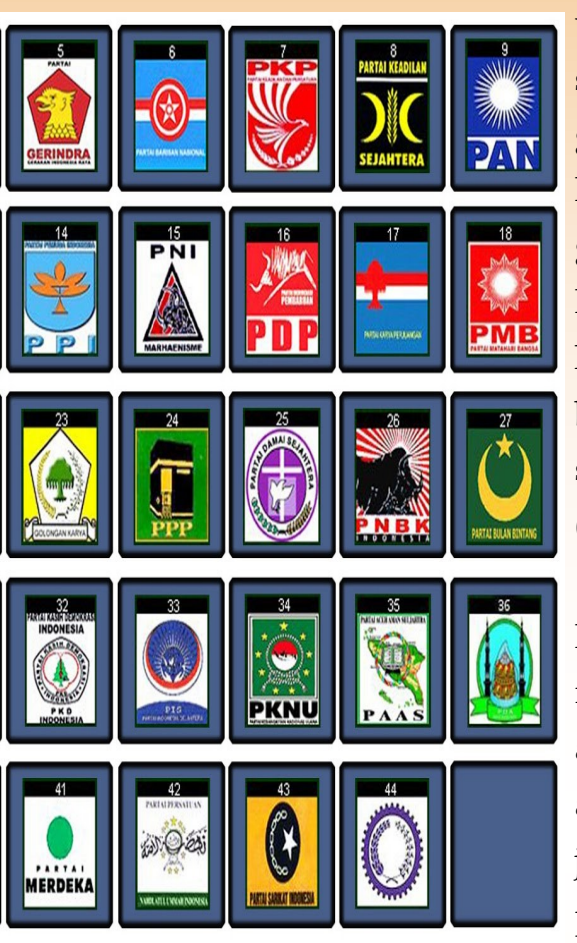
wab atas dirinya sendiri dalam pergaulan yang demokratis. Dalam pergaulan tersebut, kebebasan individu hanya boleh dibatasi oleh kebebasan yang lainnya (Fahmi, 2016: 179).

Dengan

kebebasannya,

rakyatlah yang akhirnya menjadi aktor penentu terjadinya deparpolisasi partai politik. Sehingga dampaknya, banyak partai peserta pemilu yang malah tidak mendapat suara, dan akhirnya hanya menjadi partai gurem semata.

\section{Daftar Pustaka:}

*Penulis adalah Sekjen Pusat Studi Konsitusi dan Legislasi Nasional (Posko-Legnas) UIN Syarif Hidayatullah Jakarta.

Hanafi, Muhammad. 2013. "Kedudukan Musyawarah dan Demokrasi di Indonesia." Jurnal Cita Hukum. Vol. 1 No. 2 Desember.

Fahmi, Khairul. 2016. "Menelusuri Konsep Keadilan Pemilihan Umum Dalam UUD 1945." Jurnal Cita Hukum. Vol. 4 No. 2 Desember.

'Adalah; Buletin Hukum dan Keadilan merupakan berkala ilmiah yang diterbitkan oleh Pusat Studi Konstitusi dan Legislasi Nasional (POSKO-LEGNAS), Fakultas Syariah dan Hukum UIN Syarif Hidayatullah Jakarta.

Penasehat: Prof. Dr. H. Abdul Ghani Abdullah, SH., Prof. Dr. H. A Salman Maggalatung, SH., MH. Pemimpin Redaktur: Indra Rahmatullah, Tim Redaktur: Nur Rohim Yunus, Fathuddin, Mara Sutan Rambe, Muhammad Ishar Helmi, Erwin Hikmatiar. Penyunting: Indah Furba, Hasin Abdullah. Setting \& Layout: Siti Anisaul Kamilah. 